\title{
The Nexus between Employee Motivation and Turnover Intention: Moderating Role of Generation Gap (With Special Reference to the Executives of a Leading PVC Manufacturing Firm in Sri Lanka)
}

\author{
W. A. S. S. Jayasekara ${ }^{1}$ and T. D. Weerasinghe ${ }^{2^{*}}$ \\ ${ }^{1}$ University of Salford, Manchester, United Kingdom \\ ${ }^{2}$ Department of Human Resource Management, Faculty of Commerce and \\ Management Studies, University of Kelaniya, Sri Lanka \\ ${ }^{1}$ supunsampathac@gmail.com, ${ }^{2}$ tdtmdananjaya@gmail.com \\ (iD) https://orcid.org/0000-0001-5096-6696
}

\begin{abstract}
With Human Resource Management being recognized as a strategic partner, organizations are keen on refining their existing Human Resources Management practices. Yet retaining effective and efficient employees has been a critical issue in this century. Furthermore, managing multi-generational workforce with different traits have become a widely discussed topic. Through studies, researchers have identified different factors that have an impact on employee turnover intention. This study is aimed to assess the effect of motivation on turnover intention and to assess the moderating role of generation gap between motivation and turnover intention among employees of $\mathrm{ABC}$ Private Limited. This study follows deductive approach and mono-method quantitative methodological choice with cross-sectional time horizon. Primary data was collected through a pre-tested questionnaire, which were statistically verified as reliable and valid. The data was collected from a sample of 83 executives of the ABC Private Limited and analyzed using IBM SPSS software through descriptive and inferential statistical tests.
\end{abstract}

Through the findings of this study, it is found that intrinsic motivation has a significant negative nexus with turnover intention. The direct impact of intrinsic motivation on turnover intention is also significant. Furthermore, a negative significant nexus between extrinsic motivation and turnover intention is found and the direct influence of extrinsic motivation on turnover intentions, which is significant. In addition, it is found that motivation has a significant negative nexus with turnover intention. Moreover, this study concluded declaring that generational differences significantly moderates the nexus between motivation and turnover intention. It is recommended to use a mixture of motivational factors, both intrinsic and extrinsic, to reduce employee turnover intention. Furthermore, it is suggested to consider composition of generations in the workforce when determining intrinsic and extrinsic motivation factors.

Keywords: Intrinsic motivation, Extrinsic motivation, Motivation, Turnover intention, Generation gap 


\section{Introduction}

A large number of scholars voiced their views on employee turnover in terms of it being healthy and unhealthy to an organization. On one hand, Benner (2002) stated that, high employee turnover could benefit organizations by allowing them to acquire new employees with higher energy, drive and innovative ideas. According to Lucas (2019) an organization could only capitalize on this benefit, if the value added by new employees are greater than the cost of recruitment and selection, induction, training and development of those newly hired employees.

On the other hand, organizations would have higher replacement costs, decreased productivity, reduced employee motivation and morale, reduced service and unsettled operations due to higher employee turnover (Hausknecht, Trevor \& Howard, 2009). At the same time, it will taint the organization's branding image as an employer, resulting reduced number of potential candidates applying for jobs in the organization according to Phillips and Edwards (2008). Furthermore, Hausknecht, Trevor and Howard (2009) stated that higher employee turnover leads to have a higher number of new recruits in the organization that leads to higher requirement for tight supervision and less autonomy for the employees, which leads to decreased employee motivation ultimately. The decreased employee motivation will increase the employee turnover than the previous situation that again leads to higher new recruits, lower motivation and increased employee turnover even further, forming a negative cyclical reaction. This negative cycle reduces the performance of the organization constantly until the cycle is stopped (Ton \& Huckman, 2008). Hence, it is evident that performance of an organization is adversely affected by high employee turnover.

Scholars have conducted studies to recognize the factors that influence employee turnover in organizations. Among other factors, scholars have identified significant nexus between employee turnover and work-life balance, organization-employee nexus quality, job satisfaction and motivation through their studies. Through using employee-motivating techniques among other things, some organizations have able to control employee turnover up to a certain extent. But majority of the organizations have been struggling in this aspect due to ineffective management of multi-generational workforce employed in their organizations, which includes Baby Boomers, Generation Xers and Millennials (Park \& Gursoy, 2012; Ozcelik, 2015).

\section{Statement of Problem}

ABC Pvt. Limited has a workforce of five-hundred ninety-four (594) in both factory and the head office premises, which comprises of four generations, namely Baby Boomers, Generation Xers, and Millennials Generation Zers. As any other organization, this organization is facing difficulties in retaining good employees and experiencing high employee turnover rate throughout last several years. The employee turnover rate was $18 \%, 15 \%$, $16 \%, 18 \%$ and $20 \%$ in years 2014 , 2015, 2016 and 2017 respectively. 
This high employee turnover rate has been affecting the organization negatively increasing the associated costs and reducing the overall organizational productivity. Hence, considering the aforementioned facts, the research problem of this study was raised as:

\section{What is the impact of motivation on employee turnover intention, and whether generation gap moderates the impact of motivation on employee turnover intention?}

\section{Objectives of the Study}

The core objective of the current study was to recognize various intrinsic and extrinsic motivators that motivate multi-generational workforce in the ABC Pvt. Limited. Moreover, four specific objectives were recognized for better achievement of the core objective:

- To assess the nexus between intrinsic motivation and employee turnover intention.

- To assess the nexus between extrinsic motivation and employee turnover intention.

- To assess the nexus between motivation and employee turnover intention.

- To assess the moderating effect of generation gap, between the nexus of motivation and employee turnover intention.

\section{Literature Review}

At present, organizations are trying to revamp their human resource proactively by utilizing more efficient and effective techniques in the functions of recruitment and selection, training and development of employees and retention of talented and high performing employees. Yet, majority of the organizations have failed miserably in one of the two core generic functions of HRM; maintaining an effective and efficient workforce through above functions. As Allen and Griffeth (1999) mentioned retaining of high performing employees is a critical issue faced by the organizations in $21 \mathrm{st}$ century.

\section{Turnover Intention}

Cotton and Jeffery (1986) defined turnover intention as "perceived probability of staying or leaving an employing organization". According to Purani and Sahadev (2008) and Masroor and Jamilha (2010) any potential future plan to leave the present organisation in search of another job in nearby future timeline can be defined as turnover intention. Furthermore, Simon, Müller, and Hasselhorn (2010) and McInerney, Ganotice, King, Morin and Marsh (2015) defined turnover intension in simpler terms stating that it is the effort or desire of an employee to exit from the organization. Summing up above definitions, it could be redefined as an employee's voluntary effort in planning to leave the organization, which accounts to recognizable probability of the employee leaving or remaining in the organization.

According to Fisbein and Icek (1975) employees generally make the mindful decision of leaving the organization before actually doing so. They further, stated that this nexus between the decision and action could be explained by attitude behaviour theories, which 
indicates that intent of a person to conduct himself/herself in a specific manner is the direct determinant of that specific behavior. According to above facts, turnover intention is a direct determinant of the actual employee turnover. Apart from that Cohen, Blake and Goodman (2015) stated that turnover intention has the ability to function as an excellent forecaster of existent employee turnover, through the quantitative correlational study they executed for ascertaining the nexus of actual employee turnover against turnover intention.

\section{Employee Motivation}

Shafiq, Mariam, and Raza (2011) stated Latin word 'movere' that translates to English as 'to move' is the originator of the word 'motivation'. It is few of the most extensively investigated areas with respect to HRM in the past. Due to this, one can find large number of definitions given to the word 'motivation' by different scholars across time. The inspiration, orientation and perseverance of a specific way of behaving as a result of psychological procedure is defined as motivation by Ilgen and Klein (1988), Bartol and Martin (1998) and Ryan and Deci (2002). Another definition was provided by McShane and Glinow (2000) and Sansone and Harackiewicz (2000) stating motivation as the stimuli, which spawned internally to behave in a specific way. Shanks (2007) stated the same in other words stating that the individual himself/herself should take the decision to be motivated. Shields (2007) defined motivation as an individual's strength of the willingness to perform tasks while Robbins and Coulter (2005) described it as the eagerness to apply higher energy on tasks, given that higher energy possess the ability to satisfy his/her needs. Cumulating above definitions provided by various scholars, it can be redefined as the internal psychological process, which stimulate, direct and persist the behavior of exerting a higher level of effort in carrying out a task, which has the capability to satisfy individual needs of a person.

Scholars developed theories related to motivation, which help anyone to understand what motivates individuals and how to motivate individuals. These theories are separated in to two (2) clusters; process theories and content theories. Content theories is consisted of theories that describes specific factors that motivates individuals whereas process theories explain how individuals can be motivated. Maslow's theory of hierarchy of needs, Herzberg's two factor theory, McGregor's theory X and Y, Alderfer's ERG theory and Hackman and Oldham's model of job enrichment falls under content theories, while Locke and Latham's goal setting theory, Adam's equity theory and Vroom's expectancy theory falls under process theories.

Burton (2012) defined intrinsic motivation as, being motivated by a reward generated within the action or behavior itself, without the use of external rewards to direct the behavior. Shanks (2007) defined it as the type of motivation which motivate people within themselves. Furthermore, she stated that the rewards generated are not tangible and important to each individual. Ryan and Deci (2002) 
demarcated an individual's selfcraving to discover new things and challenges as intrinsic motivation. Hence, it can be redefined as type of motivation that motivate individuals within themselves through an intangible reward spawned inside an action or a behavior itself, such as individual's self- craving to discover new things and challenges.

Extrinsic motivation involves external factors to prompt desired behavior since such behavior is generally not inherently fulfilling or enjoyable; hence, tangible rewards are given (Ryan \& Deci, 2002; Burton, 2012). Furthermore, Shanks (2007) stated that in order to acquire these tangible external rewards, individuals must prove themselves to someone. Summing up above mentioned statements by various scholars, researcher defines the extrinsic motivation as the form of motivation, which motivates individuals to prove themselves by exerting more effort in order to acquire external rewards that are tangible in nature. When comparing the two (2) types of motivation, extrinsic motivation can be considered as a shorter-term motivation approach than intrinsic motivation (Zobal, 1998).

\section{Generation Gap}

Ryder (1965) defines the term generation as a cluster of individuals with similar age who has experienced same historical events in the same time. Pilcher (1994) defined the same as individuals in a demarcated population who has experienced the identical important events in a specified time period. Kowske, Rasch and Wiley (2010) states that these clusters of individuals have shared life experiences like being born, starting school, entering and exiting workforce (retiring) in similar stages of life. Because of this, individuals in each generation has characteristics different from other generations. These characteristics defines their values, attitudes and views (Schuman \& Scott, 1989).

Social scientists have identified seven (7) different generations or cohorts: Lost Generation, G.I. Generation, Silent Generation, Baby Boomers, Generation X, Millennials (Generation $Y)$ and Generation Z. The Lost Generation or Generation of 1914 consisted of individuals who were born between 1983 and 1900. All the people in this generation is now deceased (Wohl, 1979). G.I. Generation is consisted of individuals who were born between 1901 and 1924. This generation is called the greatest generation. People who was born between 1925 and 1942 falls in to Silent Generation. They are also called as 'the lucky few' (Strauss \& Neil, 1991). Baby Boomers or $\mathrm{Me}$ Generation are the people who was born between early 1940s and 1964. Because of increased birth rates, they are largest generation of all time. People who were born between mid1960s and early 1980s are called as Generation Xers. Millennials were born between early 1980s as and mid-1990s. Generation Z consists of people who were born between mid-1990s to mid2000s. When it comes to employment, currently workforce is consisted of several generations including Baby Boomers, Generation Xers, Millennials and Generation Zers. The different generations in the workplace is defined as the generation gap in this study. 


\section{Motivation and turnover intention}

Scholars to identify the factors affecting employee turnover conducted many studies and job satisfaction, motivation, work-life balance and organization-employee nexus quality etc. have been identified as those factors. It was proven that motivation has a negative nexus with employee turnover. Gomez-Mejia and Balkin (1992), Abbas, Raja, Darr and Bouckenooghe (2014) and Shahid, Usman, Mahmood and Siddiqui (2015) stated that lower employee turnover rate was observed in organizations with motivated employees. Garg and Rastogi (2006) stated that retention of employees is possible through motivation since motivation increases the job satisfaction of employees. Omolo (2015) stated that higher job satisfaction leads to higher motivation and higher motivation leads to lower turnover. Ganta (2014) stated that employees who are not motivated tends to leave organization as soon as they see an opportunity. Above all facts suggests that there is a nexus between both intrinsic and extrinsic motivation and turnover intention.

\section{Motivation, turnover intention and the generation gap}

Prevailing studies provide contradictory views on nexus among turnover intention, motivation and generation gap. Park and Gursoy (2012) and Ozcelik (2015) expressed that there is nexus among generation gap, motivation and employee turnover while, Twenge (2010) stated there is no nexus at all.

Kowske, Rasch and Wiley (2010) found out that there is significantly different levels of job satisfaction and turnover intention between Millennials and Gen Xers, suggesting that effect of single work-related behaviour on another change depending on the generation. On one hand Park and Gursoy (2012) stated that when younger employees (Millennials and Generation Z) lose their motivation, their characteristics of weaker loyalty and lower work centrality will force them to leave the organization. On the other hand, if they are motivated, they will experience higher job satisfaction than older generations and retain in the organization (Park \& Gursoy, 2012).

According to Kicheva (2017) Generation Xers and Millennials are motivated by salary, security and achievement respectively. Twenge, Campbell and Freeman (2012) stated that generation $\mathrm{Y}$ employees prefer extrinsic motivation rather than intrinsic motivation compared to Baby Boomers, since younger generations are more materialistic oriented. Twenge J. M., Campbell, Hoffman and Lance (2010) and Twenge and Donnelly (2016) stated that Millennials value extrinsic motivators rather than intrinsic motivators than their predecessors. Hence Millennials tend to change their jobs more frequently in search of better pay, benefits and rewards to fulfil their expectations of rapid promotions which leads to higher pay and other benefits (Ng, Schweitzer, \& Lyons, 2010).

Finegold, Mohrman and Spreitzer (2002) identified number of significant differences among work-related behaviours and a different generation gap, such as job satisfaction and worklife balance, but did not find any 
significant difference between motivation drivers and different generations. Brislin, Kabigting, MacNab, Zukis and Worthley (2005) and Travis (2007) stated that in their study of demographic correlations and motivation, they found that there is no significant correlation between the different generation gap (age groups) and motivation. Giancola (2006) delivered a challenging view on motivating drivers of generation gap, stating that alleged variances of motivating drivers among generations were not empirically validated and motivation drivers are similar across all generation gap. Further, Twenge (2010) stated there is no nexus among generation gap, motivation and employee turnover.

With the extant literature regarding this matter, suggesting two contradictory opinions on their nexus, it is evident that there is a knowledge gap in this regard, whether there is a nexus among motivation, turnover intention and the generation gap.

\section{Research Methodology}

\section{Conceptual Framework}

Identified independent variables of this study were intrinsic motivation, extrinsic motivation and motivation, whereas turnover intention was identified as the dependent variable.

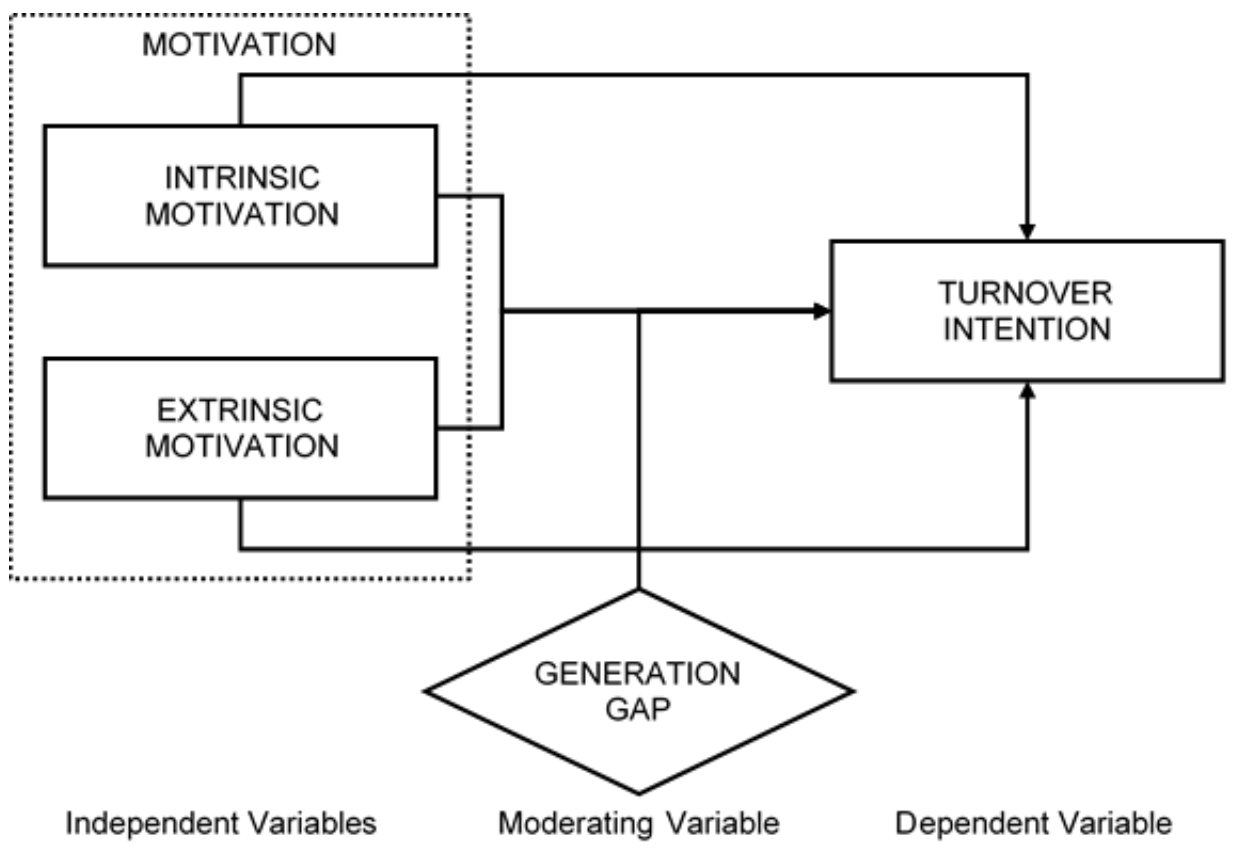

Figure 01: Conceptual Framework

Source: Authors, 2018 
Furthermore, generation gap was identified as the moderating variable of this study. Based on the variables of the study and hypotheses, conceptual framework of the study was developed as depicted in figure 1.

\section{Hypotheses of the study}

Utilizing the aforementioned evidence in prevailing literature, following hypotheses were developed to be validated statistically.

H1: There is a significant relationship between intrinsic motivation and employee turnover intention.

$\mathbf{H}_{2}$ - There is a significant relationship between extrinsic motivation and employee turnover intention.

H3: There is a significant relationship between motivation and employee turnover intention.

H4: Generation gap significantly moderates the relationship between motivation and employee turnover intention.

\section{Population and the Sample}

The population of this study were executive staff of ABC Pvt. Limited, which amounts to total of one hundred five (105). Out of the population, a sample of eighty-three (83) executive staff employees were used to collect data for the study. The sample size was determined using formula developed by Krejcie and Morgan (1970) with 95\% confidence level and 5\% margin of error from population concerned. Furthermore, simple random sampling was used to select the sample from the sampling frame.

\section{Measurement scales of the variables}

The primary data collection of this study was done using a standard, pretested questionnaire, which consisted of four (04) sections summing up to total of twenty-six (26) questions. The first section of the questionnaire was aimed to obtain basic demographic data and employment data.

The second section of the questionnaire was consisted of seven (07) items aimed to obtain data on independent variable; intrinsic motivation. The Intrinsic Job Motivation Scale, which was developed by Warr, Cook and Wall (1979) was used in the second section to acquire data on the intrinsic motivation.

The third section of the questionnaire was consisted of seven (07) items aimed to obtain data on independent variable; extrinsic motivation. The Motivation at Work Scale (MAWS), which was developed by Gagné et al (2010) was used in the third section to acquire data on the extrinsic motivation.

The fourth and the final section of the questionnaire was consisted of six (06) items to acquire data on dependent variable; turnover intention. Roodt's (2004) Turnover Intention Scale (TIS6) was used to in the fourth section of the questionnaire.

\section{Data Analysis Tools}

Data collected through the research instrument was analysed using various statistical tests. These tests were done using IBM Statistical Package for Social Sciences (SPSS) software version 23. Both descriptive and 
inferential statistical tests were used to analyse data. Descriptive statistical tools such as frequency, mean, median and standard deviation were used to present the demographic composition of the sample.

Inferential statistical tests were used to test the hypotheses of the study such as spearman's correlation, curve estimation regression. Test for normality and test for linearity are the two statistical tests which were used to identify the most appropriate statistical tests to examine the validity of the hypotheses. To test the reliability and validity of the measurement scale, reliability coefficient and EFA were used.

\section{Analysis and Result}

Sample Composition

Out of the sample, $10.8 \%$ were Baby Boomers, 32.5\% were Generation Xers and $56.6 \%$ were Millennials. $73.5 \%$ executive staff were males whereas $26.5 \%$ were females. From the sample $7.2 \%$ were in director level, $25.3 \%$ were in managerial level and 67.5 were in executive level. Highest number of respondents in the sample belonged to Sales department with $16.9 \%$ from the sample and least no of respondents belonged to Administration department with $2.4 \%$.

\section{Reliability Statistics}

All the measurement scales of research instrument obtained Cronbach's Alpha values equal or higher than 0.7 . Hence, according to the rule of thumb (as per Kaiser, 1974) the research instrument is statistically accepted as reliable.

Table 01: Reliability Statistics

\begin{tabular}{|l|c|c|c|}
\hline & $\begin{array}{c}\text { Intrinsic } \\
\text { Motivation }\end{array}$ & $\begin{array}{c}\text { Extrinsic } \\
\text { Motivation }\end{array}$ & $\begin{array}{c}\text { Turnover } \\
\text { Intention }\end{array}$ \\
\hline No. of Items & 07 & 07 & 06 \\
\hline Cronbach's Alpha & 0.842 & 0.702 & 0.816 \\
\hline
\end{tabular}

Source: Survey Data, 2018

\section{Validity Statistics}

According to the Kaiser-Meyer-Olkin measure of sampling adequacy, each measurement scale has a value that can be considered as good (as per Kaiser,
1974). Therefore, sample size is considered sufficient for the EFA and further analysis of hypotheses testing. 
Table 02: Results of Kaiser-Meyer-Olkin and Bartlett's test

\begin{tabular}{|l|c|c|c|}
\hline & $\begin{array}{c}\text { Intrinsic } \\
\text { Motivation }\end{array}$ & $\begin{array}{c}\text { Extrinsic } \\
\text { Motivation }\end{array}$ & $\begin{array}{c}\text { Turnover } \\
\text { Intention }\end{array}$ \\
\hline $\begin{array}{l}\text { Kaiser-Meyer-Olkin Measure of } \\
\text { Sampling Adequacy }\end{array}$ & 0.786 & 0.750 & 0.731 \\
\hline
\end{tabular}

Source: Survey Data, 2018

All three measurement scales have a cumulative percentage of Extraction Sums of Squared Loading higher than $50 \%$ while having factor loading of each question higher than 0.40 , which meets the standard level (Hinkin, 1995; Hinkin, 1998; Howard, 2006). Hence, validity of the scales can be verified statistically.

Table 03: Results of the EFA

\begin{tabular}{|l|c|c|c|}
\hline & $\begin{array}{c}\text { Intrinsic } \\
\text { Motivation }\end{array}$ & $\begin{array}{c}\text { Extrinsic } \\
\text { Motivation }\end{array}$ & $\begin{array}{c}\text { Turnover } \\
\text { Intention }\end{array}$ \\
\hline $\begin{array}{l}\text { Cumulative \% of Extraction Sums of } \\
\text { Squared Loadings }\end{array}$ & $72.241 \%$ & $72.975 \%$ & $69.277 \%$ \\
\hline Lowest Factor Loading Value & 0.594 & 0.631 & 0.637 \\
\hline
\end{tabular}

Source: Survey Data, 2018

\section{Correlation Analysis}

One-sample K-S test was conducted to determine the suitable correlation method. According to the results of the test, $p$ - value was less than $\alpha$ - value of
0.05 , which statistically proved that data set was not normal, hence data set was non-parametric. Therefore, Spearman's correlation was used to do the correlation analysis.

Table 04: Results of one sample Kolmogorov-Smirnov Test

\begin{tabular}{|l|l|r|r|r|r|}
\hline \multicolumn{2}{|c|}{} & $\begin{array}{c}\text { Intrinsic } \\
\text { Motivation }\end{array}$ & $\begin{array}{c}\text { Extrinsic } \\
\text { Motivation }\end{array}$ & Motivation & $\begin{array}{l}\text { Turnover } \\
\text { Intention }\end{array}$ \\
\hline $\mathrm{N}$ & 83 & 83 & 83 & 83 \\
\hline $\begin{array}{l}\text { Normal } \\
\text { Parametersa,b }\end{array}$ & Mean & 2.7074 & 3.1308 & 2.9191 & 3.2490 \\
\cline { 2 - 6 } & $\begin{array}{l}\text { Std. } \\
\text { Deviation }\end{array}$ & .52697 & .44577 & .36588 & .57933 \\
\hline $\begin{array}{l}\text { Most Extreme } \\
\text { Differences }\end{array}$ & Absolute & .180 & .154 & .182 & .162 \\
\cline { 2 - 6 } & Positive & .180 & .112 & .182 & .088 \\
\cline { 2 - 6 } & Negative & -.109 & -.154 & -.101 & -.162 \\
\hline \multicolumn{2}{|l|}{ Test Statistic } & .180 & .154 & .182 & .162 \\
\hline \multicolumn{2}{|l|}{ Asymp. Sig. (2-tailed) } & $0.000 \mathrm{c}$ & $0.000 \mathrm{c}$ & $0.000 \mathrm{c}$ & $0.000 \mathrm{c}$ \\
\hline
\end{tabular}

Source: Survey Data, 2018 
According to the results of the performed correlation analysis, which is depicted in table 5.5 spearman's correlation coefficient (rs) between turnover intention and intrinsic motivation is -0.295 , rs between turnover intention and extrinsic motivation is -0.559 and rs between turnover intention and motivation is 0.556 . Furthermore, $p$ - value for nexus between turnover intention and intrinsic motivation is $0.007, \mathrm{p}$ - value for nexus between turnover intention and extrinsic motivation is 0.000 and $\mathrm{p}$ - value for nexus between turnover intention and motivation is 0.000 , which is higher than $\alpha$ - value of 0.01 .
Using aforementioned results and guidelines provided by Xiao, Ye, Esteves and Rong (2016) on defining intensity of a relationship using correlation coefficient it is statistically concluded that there is a weak negative significant nexus between intrinsic motivation and turnover intention at $99 \%$ confidence level, there is a strong negative, but significant nexus between extrinsic motivation and turnover intention at $99 \%$ confidence level and there is a strong negative, significant nexus between motivation and turnover intention at $99 \%$ confidence level. Hence, alternative hypotheses of $\mathrm{H}_{1}, \mathrm{H}_{2}$ and $\mathrm{H}_{3}$ is statistically accepted.

Table 05: Spearman's Correlation Analysis

\begin{tabular}{|c|c|c|c|c|c|}
\hline & & & $\begin{array}{c}\text { Intrinsic } \\
\text { Motivation }\end{array}$ & $\begin{array}{c}\text { Extrinsic } \\
\text { Motivation }\end{array}$ & Motivation \\
\hline \multirow{3}{*}{$\begin{array}{l}\text { Spearman's } \\
\text { rho }\end{array}$} & \multirow{3}{*}{$\begin{array}{l}\text { Turnover } \\
\text { Intention }\end{array}$} & $\begin{array}{l}\text { Correlation } \\
\text { Coefficient }\end{array}$ & $-.295^{* *}$ & $-.559^{* *}$ & $-.556^{* *}$ \\
\hline & & $\begin{array}{l}\text { Sig. (2- } \\
\text { tailed) }\end{array}$ & .007 & .000 & .000 \\
\hline & & $\mathrm{N}$ & 83 & 83 & 83 \\
\hline
\end{tabular}

Source: Survey Data, 2018

\section{Regression Analysis}

In order to use linear regression, variables that needs to be analyzed should fulfill seven (7) assumptions; normality of residuals, presence of linear relationship between variables, outcome variable being continuous, covariates not being correlated with the error terms, having zero conditional mean error, having constant variance of errors, and having uncorrelated errors (Casson \& Farmer, 2014). Further, it states that according to central limit theorem even though the residuals does not follow the assumption of normality, if the sample size is large enough, researchers can consider that it fulfills the assumption of normality. Lumley, Diehr, Emerson and Chen (2002) stated that if a sample size is higher than fifty (50), variables does not normally violate the assumption of normality. Since, the sample size is more than fifty it can be considered that assumption of normality of residuals is fulfilled. Hence, assumption of linearity 
was tested to identify whether linear regression analysis is appropriate to perform further analysis regarding hypotheses. But according to the results obtained, it was identified that nexus between intrinsic motivation and turnover intention, extrinsic motivation and turnover intention and motivation and turnover intention are nonlinear. Therefore, curve estimation was used to perform regression analysis.

\section{Table 06: Results of Linearity Test}

\begin{tabular}{|l|l|l|l|l|}
\hline \multicolumn{2}{|c|}{} & $\begin{array}{c}\text { Turnover } \\
\text { Intention * } \\
\text { Intrinsic } \\
\text { Motivation }\end{array}$ & $\begin{array}{c}\text { Turnover } \\
\text { Intention* } \\
\text { Extrinsic } \\
\text { Motivation }\end{array}$ & $\begin{array}{l}\text { Turnover } \\
\text { Intention * } \\
\text { Motivation }\end{array}$ \\
\cline { 3 - 5 } & Sig. & Sig. & Sig. \\
\hline \multirow{3}{*}{$\begin{array}{l}\text { Between } \\
\text { Groups }\end{array}$} & (Combined) & 0.000 & 0.000 & 0.000 \\
\cline { 2 - 5 } & Linearity & 0.000 & 0.000 & 0.000 \\
\cline { 2 - 5 } & $\begin{array}{l}\text { Deviation from } \\
\text { Linearity }\end{array}$ & 0.000 & 0.000 & 0.000 \\
\hline
\end{tabular}

**.Correlation is significant at the 0.01 level (1-tailed)

Source: Survey Data, 2018

According to the curve estimation performed on the nexus between intrinsic motivation and turnover intention highest $R$ squared $\left(\mathrm{R}^{2}\right)$ value of 0.249 was obtained by the cubic model. Furthermore, $p$ - value of cubic equation is 0.000 which is below than accepted $\alpha$ - value of 0.05 . With this result it is evident that cubic equation is the best model that has higher ability to predict turnover intention using intrinsic motivation because this model represents $24.9 \%$ of variance for turnover intention that can be explained by intrinsic motivation.

Highest $\mathrm{R}^{2}$ value for the nexus between extrinsic motivation and turnover intention, quadratic model has the highest value of 0.284. Apart from that the $p$ - value of the quadratic model is below than According to the results, quadratic model has the ability to explain the variance of $28.4 \%$ of turnover intention through extrinsic motivation. Quadratic regression model have the highest $\mathrm{R}^{2}$ value of 0.345 for the nexus between motivation and turnover intention while $p$ - value of 0.000 being lower than $\alpha$ - value of 0.05 . Hence, the relationship between the variables can be statistically explained using a quadratic equation. Moreover, quadratic model has the probability of explaining a variance of $34.5 \%$ of turnover intention through motivation 
Table 07: Results of Regression Analysis

\begin{tabular}{|l|l|l|l|l|l|l|l|l|l|l|}
\hline \multicolumn{2}{|c|}{} & \multicolumn{5}{c|}{ Model Summary } & \multicolumn{3}{c|}{ Parameter Estimates } \\
\hline Nexus & Equation & $\begin{array}{l}\text { R } \\
\text { Square }\end{array}$ & F & df1 & df2 & Sig. & Con. & b1 & b2 & b3 \\
\hline $\begin{array}{l}\text { Turnover } \\
\text { Intention and } \\
\text { Intrinsic } \\
\text { Motivation }\end{array}$ & Cubic & .249 & 13.250 & 2 & 80 & .000 & 1.728 & .000 & .781 & -.200 \\
\hline $\begin{array}{l}\text { Turnover } \\
\text { Intention and } \\
\begin{array}{l}\text { Extrinsic } \\
\text { Motivation }\end{array}\end{array}$ & Quadratic & .284 & 15.574 & 2 & 80 & .000 & 4.909 & -.361 & -.053 & \\
\hline $\begin{array}{l}\text { Turnover } \\
\text { Intention and } \\
\text { Motivation }\end{array}$ & Quadratic & .345 & 21.087 & 2 & 80 & .000 & -.190 & 3.199 & -.682 & \\
\hline
\end{tabular}

Source: Survey Data, 2018

When testing the validity of $\mathrm{H}_{4}$ regression model between motivation and turnover intention was analysed separately using curve estimation among Baby Boomers, Generation Xers and Millennials. According to the test results of curve estimation Baby Boomers demonstrate quadratic model relationship between motivation and turnover intention as highest R2 value of 0.164 among other models is obtained by the same while having its $p$ - value (0.048) lower than $\alpha$-value of 0.05 . When regression analysis was performed using curve estimation R2 value of quadratic model is 0.337 , which is the highest among other models. Further, pvalue is below than the $\alpha$ - value of 0.05 . Hence, the relationship between motivation and turnover intention among Generation Xers adopts quadratic model. Unlike the nexus between motivation and turnover intention in baby boomer and Generation Xers, Millennials show a different type of nexus. According to the results of curve estimation, higher R2 value is acquired by cubic model with a value of 0.163 . At the same time, the $p$ value of cubic model is 0.020 that is below the $\alpha$-value of 0.05 .

Table 08: Results of Regression Analysis - For Generations

\begin{tabular}{|l|l|l|l|l|l|c|}
\hline & \multicolumn{2}{|c|}{ Baby Boomers } & \multicolumn{2}{c|}{ Generation Xers } & \multicolumn{2}{c|}{ Millennials } \\
\hline Equation & $\begin{array}{c}\text { R } \\
\text { Square }\end{array}$ & Sig & $\begin{array}{c}\text { R } \\
\text { Square }\end{array}$ & Sig & $\begin{array}{c}\text { R } \\
\text { Square }\end{array}$ & Sig \\
\hline Linear & .026 & .681 & .126 & .069 & .149 & .007 \\
\hline Logarithmic & .023 & .696 & .097 & .113 & .144 & .009 \\
\hline Inverse & .021 & .711 & .071 & .180 & .138 & .010 \\
\hline
\end{tabular}




\begin{tabular}{|l|l|l|l|l|l|l|}
\hline Quadratic & .164 & .048 & .337 & .007 & .161 & .021 \\
\hline Cubic & .158 & .596 & .324 & .009 & .163 & .020 \\
\hline Compound & .022 & .706 & .135 & .059 & .154 & .006 \\
\hline Power & .019 & .721 & .104 & .100 & .148 & .008 \\
\hline S & .017 & .737 & .076 & .164 & .142 & .009 \\
\hline Growth & .022 & .706 & .135 & .059 & .154 & .006 \\
\hline Exponential & .022 & .706 & .135 & .059 & .154 & .006 \\
\hline Logistic & .022 & .706 & .135 & .059 & .154 & .006 \\
\hline
\end{tabular}

Source: Survey Data, 2018

This statistically demonstrates that the nexus between motivation and turnover intention is different among three generations in terms of the fitted model. Each generation has a different nexus between same variables in the same context, which articulates that the three generations are the moderating factor in changing the nexus. Hence, due to the differences in nexus between variables, alternative hypothesis of $\mathrm{H} 4$, which stated that generation gap moderates the nexus between motivation and turnover intention is statistically accepted.

\section{Discussion of Findings}

Kuvaas (2006), Vansteenkiste et al. (2007), Samuel and Chipunza (2009), Dysvik and Kuvaas (2010), Chomal and Baruah (2014) and Imran (2017) found a negative correlation between intrinsic motivation and turnover intention. According to their findings by enhancing intrinsic motivation, turnover intention can be lowered. Through analysis performed in current study, researcher identified the effect of a significant negative nexus between the same variables among executive staff of $\mathrm{ABC}$ Pvt. Limited, confirming the verdicts above scholars presented. However, researcher observed a weak relationship between the variables, where other scholars observed a strong relationship. The reason for this difference could be the contextual differences such as the selected organization, its culture, management style and other factors. Further, $24.9 \%$ of turnover intention of executives can be explained using intrinsic motivation according to the $\mathrm{R}^{2}$ value obtained. Remaining $75.1 \%$ of turnover intention arises from other factors that are not considered in this study.

Plessis, Barkhuizen, Stanz and Schutte (2015) and Dill, Erickson and Diefendorff (2016) identified that turnover intention of employees can be reduced by increasing extrinsic motivation, which describes a negative relationship. In addition to that, Shahid, Usman, Mahmood and Siddiqui (2015) found presence of negative correlation between the above variables. According to the correlation analysis performed in this study, researcher identified presence of a significant strong and negative nexus between the same. Results of performed regression analysis produced a $\mathrm{R}^{2}$ value of 0.284 . This indicates that extrinsic motivation has an ability of $28.4 \%$ to explain turnover intention in executives at $\mathrm{ABC}$ Pvt. Limited, whereas the remaining $71.6 \%$ represents other aspects that have an effect on turnover intention among executive staff of $\mathrm{ABC}$ Pvt. Limited. 
According to the performed analysis, presence of a significant strong nexus between motivation and turnover intention is statistically proven. Furthermore, the nexus between variables was identified as negative, where turnover intention decreases when motivation is increased. Studies conducted by Gomez-Mejia and Balkin (1992), Sajjad, Ghazanfar and Ramzan (2013), Abbas, Raja, Darr and Bouckenooghe (2014), Shahid, Usman, Mahmood and Siddiqui (2015) and Omolo (2015) provided the same statistical conclusion. At the same time, Ganta (2014) expressed the same conclusion using different perspective stating that if employees are not motivated, they tend to quit from organization more often. Hence, the statistical finding obtained regarding negative association between the variables is reinforced by existing literature. Apart from that R2 value of 0.345 suggests that only $34.5 \%$ of turnover intention could be explained by motivation, whereas the remaining $65.5 \%$ of turnover intention could be due various other factors with respect to $\mathrm{ABC}$ Pvt. Limited.

As mentioned in Chapter 2: Literature Review, there are two contradicting arguments about how generation gap affects motivation and turnover intention. Twenge (2010) stated that every generation affects motivation and turnover in the same manner whereas scholars such as Park and Gursoy (2012) stated generations affects the same differently. Further, Kicheva (2017), Ng, Schweitzer and Lyons (2010) identified that each generation is motivated by different motivation factors compared to others. Moreover, Kowske, Rasch and Wiley (2010) and Finegold, Mohrman and Spreitzer (2002) stated that different generations have different work-related behaviours such as turnover intention. According to the analysis performed, researcher found that generations considered in the current study affects the nexus between the aforementioned variables differently, agreeing with the prevailing literature, which stated different generations affect above mentioned variables differently. Thus, this study concludes declaring that generational differences significantly moderates the nexus among motivation and turnover intention.

\section{Conclusion}

The conclusion demonstrates a negative correlation between motivation and turnover intention. Moreover, it was determined that only $34.5 \%$ of turnover intention is supported by motivation. According to the conclusions, turnover intention of executives of $\mathrm{ABC}$ Pvt. Limited can be lowered by enhancing the motivation level of employees. But it cannot be eliminated totally by only motivating them, since $65.5 \%$ of turnover intention is caused by various other factors, which are not tested in this study. As it was depicted in the conceptual framework, motivation is consisted of intrinsic motivation and extrinsic motivation. Therefore, an appropriate mixture of both intrinsic and extrinsic motivators can ideally be utilized to lower employee turnover intention.

\section{Recommendations}

ABC Pvt. Limited can motivate employees intrinsically by redesigning jobs to make them more meaningful, giving due recognition for achievement and developing competencies, skills and 
knowledge complying with existing policies. The organization could redesign existing jobs using Hackman and Oldham's job characteristics model. Skill variety can be increased by giving employees more task making them more complex, which require more skills to perform them. Task identity can be increased by redesigning the tasks allowing employees to complete each task by themselves, where they can claim ownership for. Moreover, task significance can be increased by delegating of tasks to employees, which will have an impact of others' lives. In addition to above autonomy can be improved by granting employees more freedom on taking decisions related to their job duties and increasing authorities of employees according to their job level. Further, feedback can be improved by advising superiors to provide constant information of their performance and ways to improve themselves. Recognition of achievement can be adopted by providing career growth opportunities depending on performances such as promotions and inculcating a culture where performance of employees are appreciated using simple words such as 'job well done' or 'thank you'. Providing constant trainings for employees will allow employees to develop themselves motivating them intrinsically.

Employees can be motivated extrinsically by providing them with rewards which satisfies basic needs. The organization can perform a salary adjustment of employees meet their physiological needs. Simultaneously, their working conditions can be improved by providing them with better infrastructure facilities. Further, the organization can take measures to increase their job security and financial security. Providing employees with rewards for desired behavior such as bonuses, increments, awards also increase extrinsic motivation of employees. These rewards provided by the organization should have a perceived value to employees to motivate them. Hence, tangible rewards as mentioned above are most common approaches that can be adopted by ABC Pvt. Limited.

To reduce the turnover intention effectively and efficiently a suitable blend of both intrinsic and extrinsic motivation factors should be employed. In order to determine the suitable mixture, findings of correlation analysis of both motivation types against turnover intention can be taken in to consideration. According to the results, a weak correlation ( $\mathrm{rs}=-0.295$ ) between intrinsic motivation and turnover intention, and a strong correlation ( $\mathrm{rs}=$ 0.559 ) between extrinsic motivation and turnover intention is found. Therefore, it is important to maintain a right trade-off between the two motivation factors giving more weightage to extrinsic motivation factors than intrinsic motivation factors, while giving due consideration to composition of generations in the workforce when determining the most suitable mixture of motivation factor to achieve the optimum outcome.

\section{Directions for Future Studies}

This study has several limitations due to various constraints. First and foremost, the study's scope was restricted to identify independent, dependent and moderating variables of motivation, turnover intention and generation gap. At the same time the study was restricted to a single organization, which is 
mentioned as ABC Pvt. Limited. Further, the selected population in the current study was limited to the executive staff of ABC Pvt. Limited. Since the population consisted of only executive staff, generations captured was limited Baby Boomers, Generation Xers and Millennials. Hence, the moderating variable of generation gap includes only those three generations

This study successfully accomplished its specific and general objectives while opening up new avenues for potential studies. The population of current study was limited to executive staff of the ABC Pvt. Limited. Studies can be conducted in the future without limiting the population for such categories, which will provide even more broad findings which can generalized even more.

Using this study as a base, researchers can replicate this study across various organizations and industries. This will cross validate the outcomes of current study and will deliver results, which can be generalized to various different contexts such as different organizations, industries and even countries.

Further, there is the possibility of incorporating more or different variables to this study changing or broadening the scope of the study. As the outcomes of current study implied, academics can analyze the effect of other aspects such as work-life balance, job satisfaction and organization-employee relationship quality on turnover intention.

When population was restricted to executive staff and the moderating variable of generation gap was also restricted to three generations of Baby Boomers, Generation Xers and Millennials. Generation Z was omitted, which is the latest addition to the workforce since there were no executives that belonged to that generation. Hence, this research provides opportunity to assess to moderating effect of generation gap including Generation $\mathrm{Z}$ for the future studies. Moreover, this study allows future studies asses the moderating effect of various other factors and provide results that will enhance the prevailing body of knowledge.

In summary current study provides a framework that can be used to conduct future studies changing the context and the content of this study, which will either confirm or create new theories.

\section{References}

Abbas, M., Raja, U., Darr, W. \& Bouckenooghe, D. (2014). Combined Effects of Perceived Politics and Psychological Capital on Job Satisfaction, Turnover Intentions and Performance. Journal of Management, 40(7), 1813-1830.

Allen, D. \& Griffeth, R. (1999). Job Performance and Turnover: A Review and Integrated Multi-route Model. Human Resource Management Review, 9(4), 525-548. 
Jayasekara \& Weerasinghe, KJHRM 2018, 13(02)

Bartol, K. M. \& Martin, D. (1998). Management. New York: McGraw-Hill.

Benner, C. (2002). Work in the New Economy: Flexible Labour Markets in Silicone Valley. Chichester: John Wiley \& Sons.

Brislin, R. W., Kabigting (Jr), F., MacNab, B., Zukis, B. \& Worthley, R. (2005). Evolving Perceptions of Japanese Workplace Motivation: An Employee Manager Comparison. International Journal of Cross-Cultural Management, 5(1), 87-104.

Burton, K. (2012). A Study of Motivation: How to Get Your Employees Moving. Indiana: Indiana University. Retrieved from https://spea.indiana.edu.

Casson, R. J., \& Farmer, L. D. (2014). Understanding and Checking the Assumptions of Linear Regression. Clinical and Experimental Ophthalmology, 42, 590596.

Chomal, N., \& Baruah, P. (2014). Performance linked reward and Job Satisfaction: Banking Sector. SCMS Journal of Indian Management, 11(4), 53-60.

Cohen, G., Blake, R. S., \& Goodman, D. (2015). Does Turnover Intention Matter? Evaluating the Usefulness of Turnover Intention Rates as a Predictor of Actual Turnover Rate. Review of Personnel Administration, 36(3), 1-24.

Dill, J., Erickson, R. J., \& Diefendorff, J. M. (2016). Motivation in Caring Labor: Implications for the Well-being and Employment Outcomes of Nurses. Social Science \& Medicine, 167, 99-106.

Dysvik, A., \& Kuvaas, B. (2010). Exploring the Relative and Combined Influence of Mastery-approach Goals and Work Intrinsic Motivation on Employee Turnover Intention. Personnel review, 39(5), 622-638.

Finegold, D., Mohrman, S., \& Spreitzer, G. M. (2002). Age Effects on the Predictors of Technical Workers' Commitment and Willingness to Turnover. Journal of Organizational Behavior, 23, 655-674.

Fisbein, M., \& Icek, A. (1975). Belief, Attitude, Intention and Behavior: An Introduction to Theory and Research. Massachusetts: Addison-Wiley Publishing Company.

Gagné, M., Forest, J., Gilbert, M. H., Aubé, C., Morin, E., \& Malorni. (2010). The Motivation at Work Scale: Validation Evidence in Two Languages. Educational and Psychological Measurement, 70, 628-646.

Ganta, V. C. (2014). Motivation in the Workplace to Improve the Employee Performance. International Journal of Engineering Technology Management and Applied Sciences, 2(6), 221-230.

Garg, P., \& Rastogi, R. (2006). New Model of Job Design: Motivating Employee Performance. Journal of Management Development, 25(6), 572-587.

Giancola, F. (2006). The Generation Gap: More Myth than Reality. Human Resource Planning, 29(4), 32-37. 
Gomez-Mejia, L. R., \& Balkin, D. B. (1992). Compensation, Organisational Strategy and Firm Performance. Mason, Ohio: South-Western Publishing.

Hausknecht, J., Trevor, C., \& Howard, M. (2009). Unit-level Voluntary Turnover Rates and Customer Service Quality: Implications of Group Cohesiveness, Newcomer Concentration and Size. Journal of Applied Psychology, 94(4), 1068-1075.

Hinkin, T. R. (1995). A Review of Scale Development Practices in the Study of Organizations. Journal of Management, 21, 967-988.

Hinkin, T. R. (1998). A brief Tutorial on the Development of Measures for use in Survey Questionnaires. Organizational Research Methods, 1, 104-121.

Howard, M. (2006). A Review of Exploratory Factor Analysis Decisions and Overview of Current Practices: What We Are Doing and How Can We Improve? International Journal of Human-Computer Interaction, 32(1), 5162.

Ilgen, D., \& Klein, H. (1988). Individual Motivation and Performance: Cognitive Influences on Effort and. In J. Campbell, \& R. Campbell (Eds.), Productivity in Organizations. London: Jossey-Bass.

Imran, M. (2017). Impact of Intrinsic Factors of Motivation on Employee's Intention to Leave: A Case Study of Health Department District Okara Punjab, Pakistan. Arabian Journal of Business and Management Review, 7(3), 308312.

Kaiser, H. F. (1974). An index of factorial simplicity. Psychometrika, 39, 31-36.

Kicheva, T. (2017). Management of Employees from Different Generations Challenge for Bulgarian Managers and HR Professionals. Economic Alternatives, 1, 103-121.

Kowske, B. J., Rasch, R., \& Wiley, J. (2010). Millennials'(lack of) Attitude Problem: An Empirical Examination of Generational Effects on Work Attitudes. Journal of Business and Psychology, 25(2), 265-279.

Krejcie, R. V., \& Morgan, D. (1970). Determining Sample Size for Research Activities. Educational and Psychological Measurement, 30, 607-610.

Kuvaas, B. (2006). Performance Appraisal Satisfaction and Employee Outcomes: Mediating and Moderating roles of Motivation. The International Journal of Human Resource Management, 17(3), 504-522.

Lucas, S. (2017). Know the Costs (and benefits) of Employee Turnover? The Balance. Retrieved December 3, 2018, from https:/www.thebalance.com/the-costsand-benefits-ofemployee-turnover-1918271

Lumley, T., Diehr, P., Emerson, S., \& Chen, L. (2002). The importance of the normality assumption in large public health data sets. Annual Review of Public Health, 23, 151-169. 
Jayasekara \& Weerasinghe, KJHRM 2018, 13(02)

Masroor, M. A., \& Jamilha, M. F. (2010). Level of Job Satisfaction and Intention to Leave among Malaysian Nurses. Business Intelligence Journal, 3, 123-137.

McInerney, D. M., Ganotice, F. A., King, R. B., Morin, A. J., \& Marsh, H. W. (2015). Teachers' Commitment and Psychological Well-being: Implications of Selfbeliefs for Teaching in Hong Kong. Educational Psychology, 35(6), 926-945.

McShane, S., \& Glinow, M. V. (2000). Organizational Behavior. New York: McGraw-Hill.

Ng, E. S., Schweitzer, L., \& Lyons, S. T. (2010). New Generation, Great Expectations: A Field Study of the Millennial Generation. Journal of Business and Psychology, 25, 281-292.

Omolo, P. A. (2015). Effect of Motivation on Employee Performance of Commercial Banks in Kenya: A Case Study of Kenya Commercial Bank in Migori County. International Journal of Human Resource Studies, 5(2), 87-103.

Ozcelik, G. (2015). Engagement and Retention of the Millennial Generation in the Workplace through Internal Branding. International Journal of Business and Management, 10(3), 99-107.

Park, J., \& Gursoy, D. (2012). Generation Effects on Work Engagement among U.S. Hotel Employees. International Journal of Hospitality Management, 31, 1195-1202.

Phillips, J., \& Edwards, L. (2008). Managing Talent Retention: An ROI Approach. Somerset: John Wiley \& Sons.

Pilcher, J. (1994). Mannheim's Sociology of Generations: An Undervalued Legacy. British Journal of Sociology, 45, 481-495.

Plessis, L. D., Barkhuizen, N., Stanz, K., \& Schutte, N. (2015). The Management Side of Talent: Causal Implications for the Retention of Generation Y Employees. Journal of Applied Business Research, 31, 1767-1779.

Purani, K., \& Sahadev, S. (2008). The Moderating Role of Industrial Experience in the Job Satisfaction, Intention to Leave Relationship: An Empirical Study among Salesmen in India. Journal of Business \& Industrial Marketing, 23, 475-485.

Robbins, S. P., \& Coulter, M. (2005). Management. New Jersey: Pearson Prentice Hall.

Roodt, G. (2004). Turnover Intentions. Johannesburg.

Ryan, R., \& Deci, E. (2002). Self-determination Theory and the Facilitation of Intrinsic Motivation, Social Development and Well-being. American Psychologist, 55(1), 68-78.

Ryder, N. B. (1965). The Cohort as a Concept in the Study of Social Change. American Sociological Review, 30, 843-861. 
Sajjad, A., Ghazanfar, H., \& Ramzan, D. M. (2013). Impact of Motivation on Employee Turnover in Telecom Sector of Pakistan. Journal of Business Studies Quarterly, 5(1), 76-92.

Samuel, M. O., \& Chipunza, C. (2009). Employee Retention and Turnover: Using Motivational Variables as a Panacea. African journal of business management, 3(9), 410-411.

Sansone, C., \& Harackiewicz, J. M. (Eds.). (2000). Intrinsic and Extrinsic Motivation: The Search for Optimal Motivation and Performance. San Diego: CA: Academic Press.

Schuman, H., \& Scott, J. (1989). Generations and collective memories. American Sociological Review, 54(3), 359-381.

Shafiq, M. M., Mariam, M., \& Raza, M. S. (2011). Association between Reward and Employee Motivation: A Case Study Banking Sector of Pakistan. European Journal of Humanities and Social Sciences, 5(1), 165-178.

Shahid, H., Usman, M., Mahmood, F., \& Siddiqui, K. (2015). The Relationship between Reward Management System and Turnover Intention: Mediating Role of Motivation. International Review of Social Sciences, 3(10), 440-450.

Shanks, N. H. (2007). Management and Motivation. In S. B. Buchbinderand, \& N. Shanks (Eds.), Introduction to Health Care Management (pp. 23-36). Sudbury, Massachusetts: Jones and Bartlett Publishers.

Shields, J. (2007). Managing Employee Performance and Reward: Concepts, Practices, Strategies. Cambridge University Press.

Simon, M., Müller, B. H., \& Hasselhorn, H. M. (2010). Leaving the Organization or the Profession - A Multilevel Analysis of Nurses' Intentions. Journal of Advanced Nursing, 66(3), 616-626.

Strauss, W., \& Nei, 1. H. (1991). Generations: The History of Americas Future, 1584 to 2069. New York: Harper Perennial.

Ton, Z., \& Huckman, R. (2008). Managing the Impact of Employee Turnover on Performance: The Role of Process Conformance. Organization Science, 19(1), 56-68.

Travis, D. J. (2007). Is Doing Good Enough? A Path Analytic Model of Intrinsic Job Satisfaction among Human Service Workers. Journal of Workplace Behavioral Health, 22(1), 13-32.

Twenge, J. M. (2010). A Review of the Empirical Evidence on Generational Differences in Work Attitudes. Journal of Business and Psychology, 25(2), 201-210.

Twenge, J. M., \& Donnelly, K. (2016). Generational Differences in American Students Reasons for Going to College: The Rise of Extrinsic Motives. The Journal of Social Psychology, 156(6), 620-629. 
Jayasekara \& Weerasinghe, KJHRM 2018, 13(02)

Twenge, J. M., Campbell, S. M., Hoffman, B. J., \& Lance, C. E. (2010). Generational Differences in Work Values: Leisure and Extrinsic Values Increasing, Social and Intrinsic Values Decreasing. Journal of Management, 36, 1117-1142.

Twenge, J. M., Campbell, W., \& Freeman, E. (2012). Generational Differences in Young Adults' Life Goals, Concern for Others, and Civic Orientation, 1966 2009. Journal of Personality and Social Psychology, 102(45), 1045-1062.

Vansteenkiste, M., Neyrinck, B., Niemiec, C., Soenens, B., De Witte, H., \& Van den Broeck, A. (2007). On the Relations among Work Value Orientations, Psychological Need Satisfaction and Job Outcomes: A Selfdetermination Theory Approach. Journal of Occupational and Organizational Psychology, 80(2), 251-277.

Warr, P., Cook, J., \& Wall, T. (1979). Scales for the Measurement of some Work Attitudes and Aspects of Psychological Well-being. Journal of Occupational Psychology, 52, 129-148.

Wohl, R. (1979). The generation of 1914. Cambridge, Massachusetts: Harvard University Press.

Xiao, C., Ye, J., Esteves, R. M., \& Rong, C. (2016). Using Spearman's Correlation Coefficients for Exploratory Data Analysis on Big Dataset. Concurrancy and Computaion; Practice and Experience, 28(14), 3866-3878.

Zobal, C. (1998). The "Ideal” Team Compensation System-an Overview: Part I, Team Performance Management. An International Journal, 4(5), 235-249. 